\title{
Petrophysical Evaluation and the Effect of Shale Layers on Net Pay Zone Thickness in the Marun Oil Field, Iran
}

\author{
Saeed Tajali, Mehran Arian* \\ Department of Geology, Science and Research Branch, Islamic Azad University, Tehran, Iran \\ Email: "mehranarian@yahoo.com
}

Received 22 June 2016; accepted 14 August 2016; published 17 August 2016

Copyright $@ 2016$ by authors and Scientific Research Publishing Inc.

This work is licensed under the Creative Commons Attribution International License (CC BY). http://creativecommons.org/licenses/by/4.0/

(c) (i) Open Access

\section{Abstract}

The Marun oil field is situated on the eastern part of Zagros, Iran. Aghajari Formation is cropping out on the surface. The Asmari formation, the Bangestan and Khami Groups are the Main reservoirs in this field and Asmari formation is the most important reservoir. Dolomitic carbonates are dominant lithology in the study well. Increasing of shale Layers in different layers caused to decrease of brittle property and this condition had investigated by petrophysical evaluation. According to this research, near to 29 percent shale has mixed with sandstone rock units in the study well which is comparable with maximum porosity there. Because, sandstone layers have shown the best porosity (near to 26 percent) in the study well. Also, good rocks based on water saturation and porosity are situated in sandstone units and poor rocks have existed in the limestonedolomites. Therefore, facies changes in the Asmari formation can explain the observed variations in reservoir quality in the study area.

\section{Keywords}

Asmari Formation, Marun Oil Field, Petrophysical Evaluation, Well Logging

\section{Introduction}

The Marun oil field has located in the south east of Ahwaz city on the south west of Iran. It has got $65 \mathrm{Km}$ length and $8 \mathrm{Km}$ width on the Zagros fold-and-thrust belt. The Oligocene-lower Miocene [1]-[4] limestones and sandstone of the Asmari formation are the most important reservoirs in Iran.

The formation is categorized as the main reservoir of so many fields in the south western Iran. In general, due

\footnotetext{
"Corresponding author.
} 
to its importance in petroleum geology, the study of Asmari formation has been always considered as an area of interest for many researchers. The formation consists of 300 - 500 meters thick gray limestone, with shale and clay beds in this area.

According to [5], Marun Anticline is a fault (thrust) related fold with faulted Detachment Fold mechanism. Two major fractures system in the Marun oil field could be recognized which are regional fractures (with east-west trending) and local fractures (fold and bending related fractures). The main fractured sectors, Marun Anticline, are being seen in the southern limb and the eastern part of northern limb by curvature investigation (by Differential and Graphical methods). The results of Iso-permeability, RFT, PI maps are consisted with the results of fracture study in order to identify fractured sectors in the Marun Anticline.

\subsection{Location}

The numerous studies of the Zagros, Iran which have been made, relatively little has been published concerning the Petrophysical evaluation and the effect of shale layers on net pay zone thickness of Marun oil field. Marun oil field is situated on the eastern part of Dezful Embayment zone (Zagros). Aghajari Formation is cropping out on the surface. Asmari formation, Bangestan and Khami Groups are the Main reservoirs in this field.

\subsection{Geology Setting}

The study area has situated on Zagros province. Dominant structural trends in Zagros province are NW-SE in northwestern part and E-W in southeastern part. From tectonics view, it contains the overthrust and simple fold belts of Zagros that formed on the northeastern part of Arabian plate's passive margin. Zagros Mountains have continued to East Taurus Mountains in Turkey and have named Zagros-East Taurus hinterland. Zagros-East Taurus hinterland is external platform (fold and thrust belt) of north margin of Arabian Craton. The vergence of folding in this hinterland is toward south and southwest [6]-[8].

\section{Materials and Methods}

For the preparation of the porosity from the density log, consideration of matrix values and fluid properties are necessary. Also, shale properties must be considered for sedimentary sequences for each interval [9] was obtained from well data. These values were then adjusted and corrected based on the data sources by use of Schlumberger charts. The chart is used to convert density to porosity. Values of log-derived bulk density ( $\left.\rho_{b}\right)$ corrected for borehole size, matrix density to the formation $\left(\rho_{\mathrm{ma}}\right)$, and fluid density $\left(\rho_{f}\right)$ are used to determine the density porosity $\left(\varphi_{D}\right)$ of logged formation.

The $\rho_{f}$ is the density of the fluid saturating the rock immediately surrounding the borehole and it can be show by below formula no. 1 [10];

$$
\varphi=\left(\rho_{m a}-\rho_{b}\right) /\left(\rho_{m a}-\rho_{f}\right) .
$$

Then, ranges porosity (Figure 1) and water saturation (Figure 2), have prepared for all intervals of the well.

The rock types were determinate based on the porosity and water saturation for all intervals of the well by use of Table 1.

The net thickness $\left(h_{n e t}=368.04\right)$ was calculated by remove of the shale, Dense Rock and Wet Rock intervals. Then charts of shale volume percent, the corrected and measured porosity were prepared (Figure 3 and Figure 4).

The corrected net to gross thickness $\left(\left(h_{\text {net/gross }}\right)_{\text {corrected }}\right)$ and corrected average of porosity $\left(\left(\varphi_{\text {ave }}\right)\right.$ corrected $)$ have calculated by [10]-[18] use of below formulas no. (2)-(4):

$$
\begin{gathered}
\left(h_{\text {net }}\right)_{\text {corrected }}=\left((h)_{g}\right)_{\text {corrected }}+\left((h)_{f}\right)_{\text {corrected }}+\left((h)_{p}\right)_{\text {corrected }} \\
\left(\frac{\text { Net }}{\text { Gross }}\right)_{\text {corrected }}=\frac{\left((h)_{\text {net }}\right)_{\text {corrected }}}{(h)_{\text {gross }}} \\
\left(\varphi_{\text {ave }}\right)_{\text {corrected }}=\frac{\left(\left(\sum \varphi \cdot h\right)_{g}\right)_{\text {corrected }}+\left(\left(\sum \varphi \cdot h\right)_{f}\right)_{\text {corrected }}+\left(\left(\sum \varphi \cdot h\right)_{p}\right)_{\text {corrected }}}{\left(\left(\sum h\right)_{g}\right)_{\text {corrected }}+\left(\left(\sum h\right)_{f}\right)_{\text {corrected }}+\left(\left(\sum h\right)_{p}\right)_{\text {corrected }}} .
\end{gathered}
$$




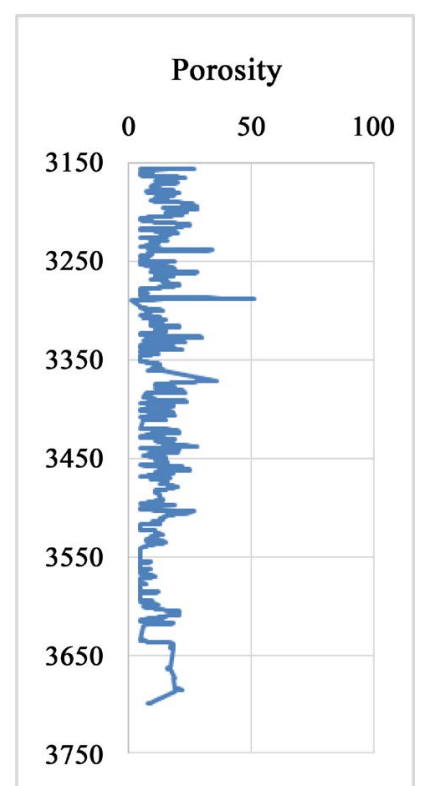

Figure 1. The corrected porosity chart of the study well.

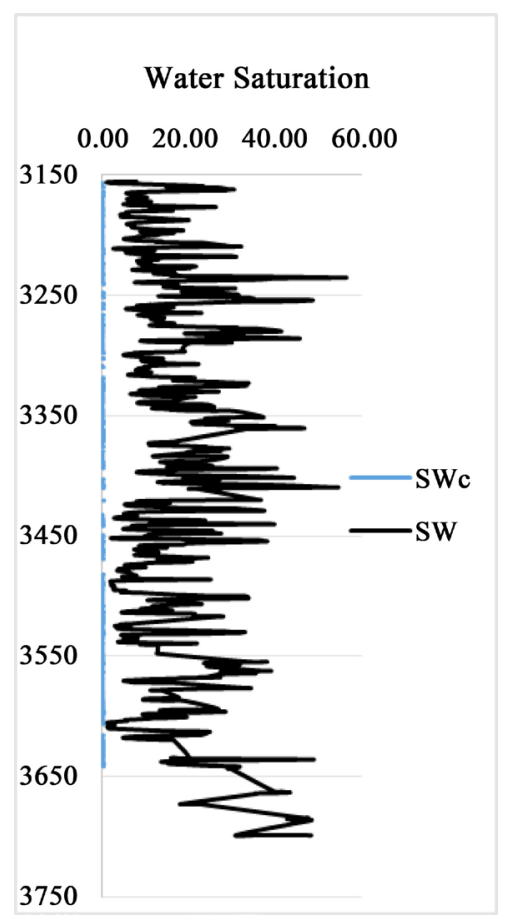

Figure 2. The corrected water saturation (SWc) and water saturation (SW) charts of the study well.

Table 1. The rock types based on water saturation and porosity.

\begin{tabular}{ccc}
\hline (SW \%) & $(\boldsymbol{\Phi} \%)$ & Rock Type \\
\hline $0-25$ & $8 / 5-100$ & GOOD ROCK \\
$25-50$ & $8 / 5-100$ & FAIR ROCK \\
$0-50$ & $4 / 5-8 / 5$ & POOR ROCK \\
$0-100$ & $0-4 / 5$ & DENSE ROCK \\
$50-100$ & $4 / 5-100$ & WET ROCK \\
\hline
\end{tabular}




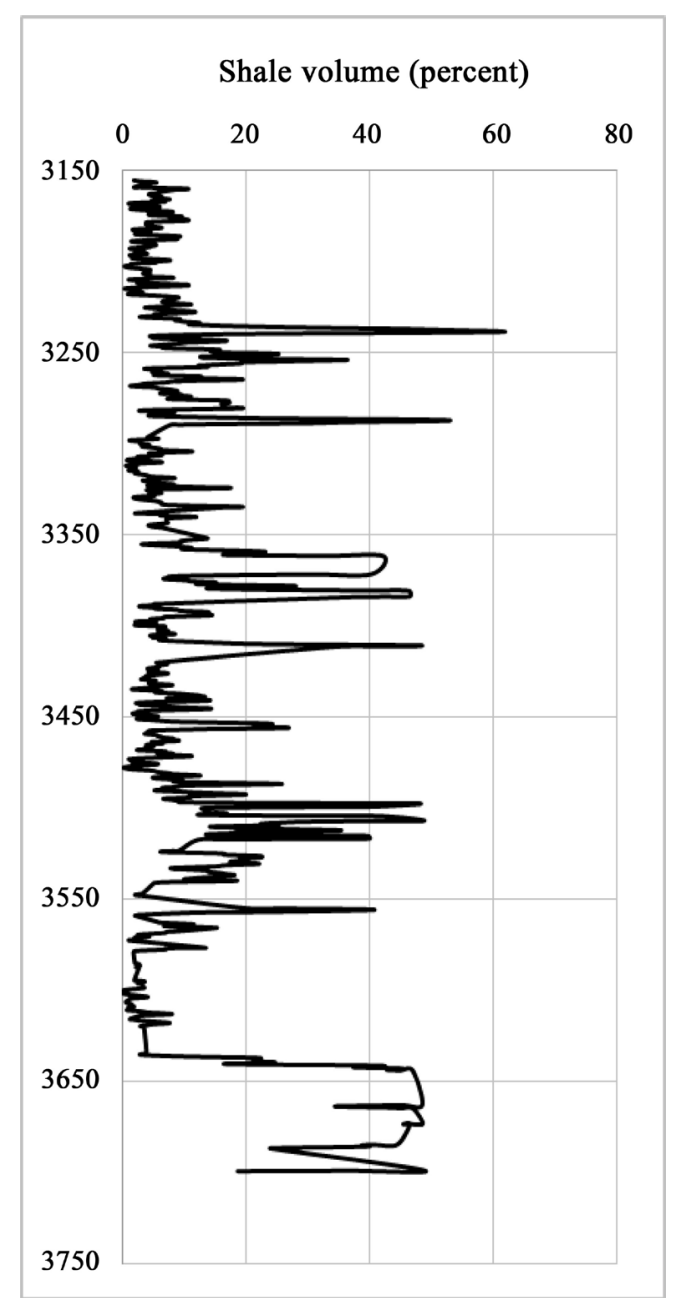

Figure 3. The percent of shale volume graph in the study well.

Then, the corrected average of water saturation $\left(\left(S W_{\text {ave }}\right)_{\text {corrected }}\right)$ has calculated by use of below formula no. (5):

$$
\left(S W_{\text {ave }}\right)_{\text {corrected }}=\frac{\left(\left(\sum \varphi \cdot h \cdot S W\right)_{g}\right)_{\text {corrected }}+\left(\left(\sum \varphi \cdot h \cdot S W\right)_{f}\right)_{\text {corrected }}+\left(\left(\sum \varphi \cdot h \cdot S W\right)_{p}\right)_{\text {corrected }}}{\left(\left(\sum \varphi \cdot h\right)_{g}\right)_{\text {corrected }}+\left(\left(\sum \varphi \cdot h\right)_{f}\right)_{\text {corrected }}+\left(\left(\sum \varphi \cdot h\right)_{p}\right)_{\text {corrected }}} .
$$

And finally, the corrected net hydrocarbon column $\left((\mathrm{N} \cdot \mathrm{H} \cdot \mathrm{C})_{\text {corrected }}\right)$ has calculated by use of below formula no. (6):

$$
(N \cdot H \cdot C)_{\text {corrected }}=\left(\varphi_{\text {ave }}\right)_{\text {corrected }}\left(h_{\text {net }}\right)_{\text {corrected }}\left(1-\left(S W_{\text {ave }}\right)_{\text {corrected }}\right) .
$$

\section{Results and Discussion}

The study area is situated in Zagros fold and thrust belt (Figure 1). From tectonics view, it contains orogenic belt of Arabian plate. Based on previous work on the salt and mud diapirism [19]-[33] and neotectonic regime in Iran [34]-[39], Zagros is the most active zone [40]-[67]. Then, Alborz [68]-[109] and Central Iran [110]-[127] have been situated in the next orders. Therefore, active tectonics have got an important rule on the petrophysical properties of Asmari formation in the study area. The results of petrophysical evaluation have been shown in Table 2.

The calculated values for the net thickness $\left(h_{\text {net }}\right)$, average porosity $\left(\varphi_{\text {ave }}\right)$, average of water saturation $\left(S W_{\text {ave }}\right)$, the net to gross thickness $\left(h_{\text {net }} / h_{\text {gross }}\right)$ and the net hydrocarbon column $(N \cdot H \cdot C)$ as normal and corrected have 
presented in details. They are showing that the corrected values are less than normal values and the corrections must be consider in petrophysical evaluations of hydrocarbon wells. Also, lithologic distribution related to lithology percent, shale percent and porosity percent have shown in Figure 5. They have shown that limestone is the dominant rock in this reservoir and sandstone layers have got the maximum porosity. Figure 6 is showing that near to 29 percent shale has mixed with sandstone rock units in the study well that consist with maximum porosity there (near to 26 percent).

\section{Conclusions}

The Limestones, Dolomites and Shale are dominant lithology in the study well at Asmari reservoir of the Marun oil field, Zagros Iran. The values for the net thickness $\left(H_{\text {net }}\right)$, average porosity $\left(\varphi_{\text {ave }}\right)$, average of water saturation $\left(S W_{\text {ave }}\right)$, the net to gross thickness $\left(h_{\text {net }} / h_{\text {gross }}\right)$ and the net hydrocarbon column $(N \cdot H \cdot C)$ as normal and corrected

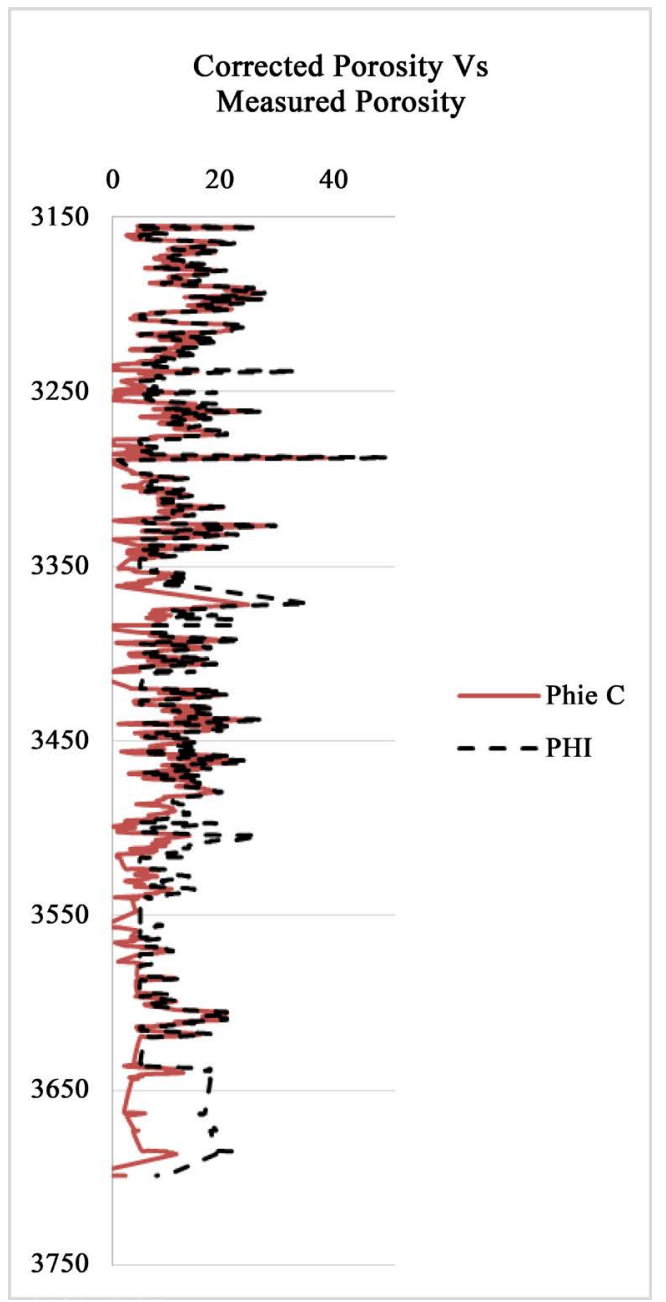

Figure 4. The corrected porosity and measured porosity graphs in the study well.

Table 2. The petrophysical properties of Asmari formation in the study well.

\begin{tabular}{ccc}
\hline Item & Normal & Corrected \\
\hline$h_{\text {net }}$ & $368.04 \mathrm{~m}$ & $314.39 \mathrm{~m}$ \\
$\varphi_{\text {ave }}$ & 13.3 & 11.7 \\
$S W_{\text {ave }}$ & 13.71 & 0.14 \\
$h_{\text {nee }} / h_{\text {gross }}$ & 0.665 & 0.5679 \\
$\mathrm{~N} \cdot \mathrm{H} \cdot \mathrm{C}$ & $42.238 \mathrm{~m}$ & $36.71 \mathrm{~m}$ \\
\hline
\end{tabular}



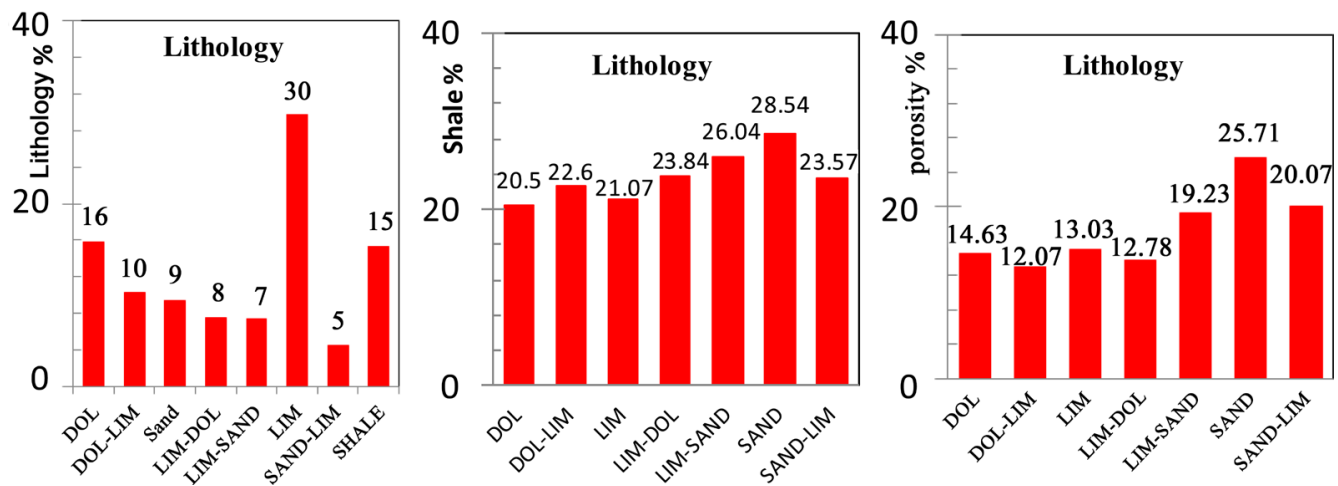

Figure 5. Lithology distribution related to lithology percent, shale percent and porosity percent.

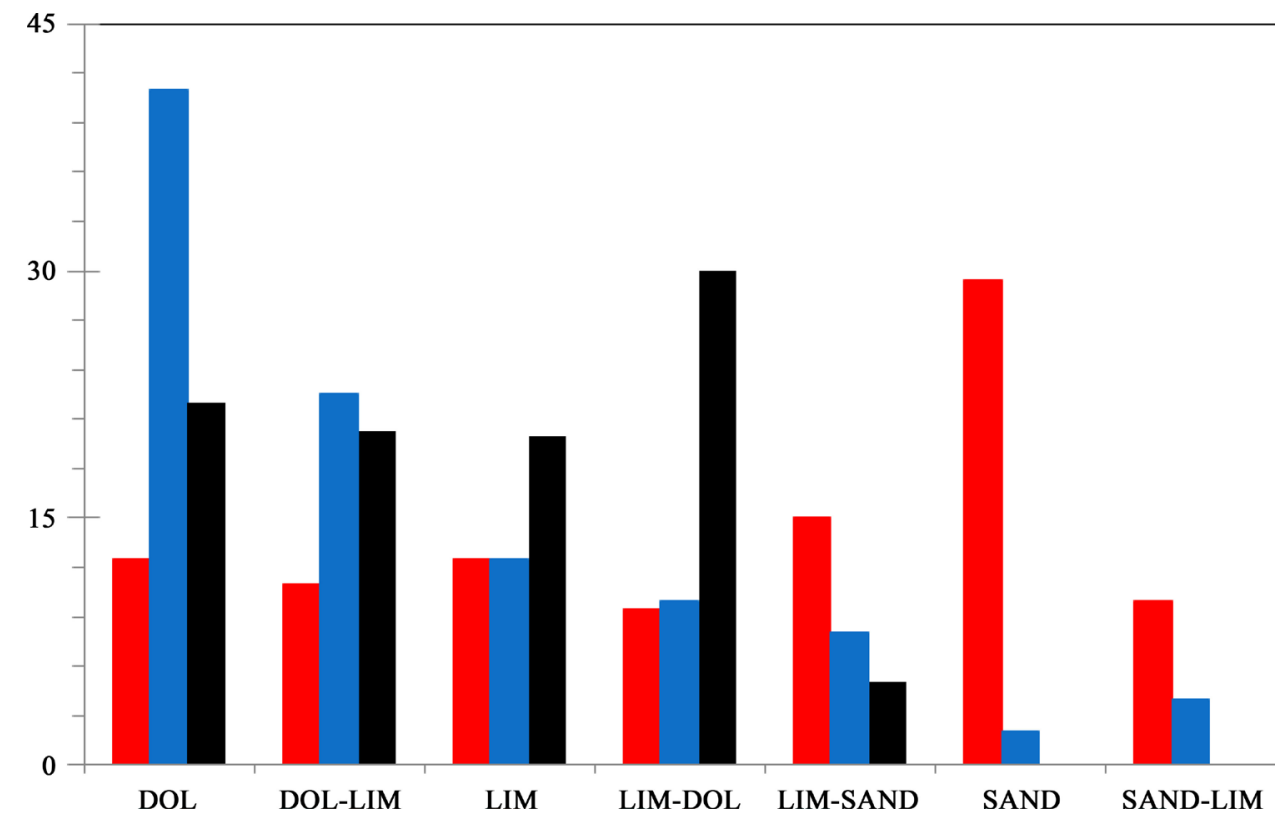

Figure 6. Lithology distribution related to the rock type percent. The good, fair and poor rocks have shown with red, blue and black colors, respectively.

were calculated. They are showing that the corrected values are less than normal values and the corrections must be considered in petrophysical evaluations of the hydrocarbon wells.

Based on this research, 28.54 percent shale has mixed with sandstone rock units in the study well which is comparable with maximum porosity there. Because, sandstone layers have shown the best porosity (25.71 percent) in the study well. Also, based on water saturation and porosity, good rocks are situated in sandstone units and poor rocks have existed in the limestone-dolomites layers. Therefore, facies changes in the Asmari Formation can explain the observed variations in reservoir quality in the study area.

\section{Acknowledgements}

This study was conducted as a part of M.Sc. degree granted by Islamic Azad University, Science and Research Branch, Tehran Iran. The author would like to acknowledge, with deep appreciation and gratitude, invaluable help of the staff of Research \& Development Department and experts of Iranian Offshore Oil Company \& Schlumberger Company for providing us with guidance, required data, and well data.

\section{References}

[1] Vaziri-Moghaddam, H., Kimiagari, M. and Taheri, A. (2006) Depositional Environment and Sequence Stratigraphy of 
the Oligo-Miocene Asmari Formation in SW Iran. Facies, 52, 41-51. http://dx.doi.org/10.1007/s10347-005-0018-0

[2] McQuillan, H. (1973) Small-Scale Fracture Density in Asmari Formation of Southwest Iran and Its Relation to Bed Thickness and Structural Setting. AAPG Bulletin, 57, 2367-2385.

http://dx.doi.org/10.1306/83d9131c-16c7-11d7-8645000102c1865d

[3] Wennberg, O.P., Svånå, T., Azizzadeh, M., Aqrawi, A.M.M., Brockbank, P., Lyslo, K.B. and Ogilvie, S. (2006) Fracture Intensity vs. Mechanical Stratigraphy in Platform Top Carbonates: The Aquitanian of the Asmari Formation, Khaviz Anticline, Zagros, SW Iran. Petroleum Geoscience, 12, 235-246. http://dx.doi.org/10.1144/1354-079305-675

[4] Ehrenberg, S.N., Pickard, N.A.H., Laursen, G.V., et al. (2007) Strontium Isotope Stratigraphy of the Asmari Formation (Oligocene-Lower Miocene), SW Iran. Journal of Petroleum Geology, 30, 107-128. http://dx.doi.org/10.1111/j.1747-5457.2007.00107.x

[5] Arian, M. and Mohammadian, R. (2011) Analysis of Fractures in the Asmari Reservoir of Marun Oil Field (Zagros, Iran). Geosciences, 20, 87-96.

[6] Arian, M. (2013) Physiographic-Tectonic Zoning of Iran’s Sedimentary Basins. Open Journal of Geology, 3, 169-177. http://dx.doi.org/10.4236/ojg.2013.33020

[7] Qorashi, M. and Arian, M. (2011) Tectonics of Iran. Geologic Survey of Iran, Tehran, 336 p.

[8] Arian, M. (2011) Basement Tectonics and Geology of Iran. Asar Nafis Press, Qum, 300 p.

[9] Patchett, G. (1975) An Investigation of Shale Conductivity. Log Analyst, 16, 25.

[10] Schlumberger (2009) Log Interpretation Charts. 232 p.

[11] Hearst, G.R., Nelson, P.H. and Paillet, F.L. (2000) Well Logging for Physical Properties. John Wyllie and Sons, Ltd., Chichester.

[12] Anselmetti, F.S. and Eberli G.P. (1999) The Velocity Deviation Log: A Tool to Predict Pore Type Permeability Trends in Carbonate Drill Holes From Sonics And Porosity or Density Logs. AAPG Bulletin, 83, 450-466.

[13] Burke, J.A., Schmidt, A.W. and Campbell, R.L. (1969) The Litho/Porosity Cross Plot. Log Analyst, $10,25$.

[14] Archie, G.E. (1942) The Electrical Resistivity Log as an Aid in Determining Some Reservoir Characteristics. Transactions of the AIME, 146, 54-62.

[15] Sundberg, K. (1932) Effect of Impregnating Waters on Electrical Conductivity of Soils and Rocks. Petroleum Transactions of AIME, 97, 367-391.

[16] Pickett, G.R. (1966) A Review of Current Techniques for Determination of Water Saturation. Journal of Petroleum Technology, 18, 1425-1433. http://dx.doi.org/10.2118/1446-PA

[17] Worthington, D.F. (1985) The Evolution of Shaly-Sand Concept in Reservoir Evaluation. The Log Analyst, 26, 1-13.

[18] Rezaee, M.R. and Lemon, N. (1996) Petrophysical Evaluation of Kaolin-Bearing Sandstones, I: Water Saturation, an Example of the Tirrawarra Sandstone Reservoir, Cooper Basin Australia. SPE Paper 37023, 539-549.

[19] Arian, M. (2011) A Preface on Salt Diapirism of Iran. Asar Nafis Press, Qum, 309 p.

[20] Arian, M. and Noroozpour, H. (2015) The Biggest Salt-Tongue Canopy of Central Iran. Open Journal of Geology, 5, 55-60. http://dx.doi.org/10.4236/ojg.2015.52005

[21] Asadian, F., Pourkermani, M. and Arian, M. (2007) Tectonic Geomorphology of Salt Structures in the GarmsarLasjerd Area. Geographical Research, 39, 75-84.

[22] Pourkermani, M. and Arian, M. (1997) Salt Domes of Central Iran. Journal of Humanities, 3, 29-41.

[23] Arian, M. (2012) Salt Diapirism and Tectonics. 2nd Edition, Asar Nafis Press, Qum, 319 p.

[24] Arian, M. and Noroozpour, H. (2015) Tectonic Geomorphology of Iran’s Salt Structures. Open Journal of Geology, 5, 61-72. http://dx.doi.org/10.4236/ojg.2015.52006

[25] Asadian, F. and Arian, M. (2009) Identification of Diapiric Provinces of Central Iran through Geological and Geographical Analysis. International Journal of Agriculture Environment \& Biotechnology, 2, 3443-3451.

[26] Arian, M. (2012) Clustering of Diapiric Provinces in the Central Iran Basin. Carbonates and Evaporites, 27, 9-18. http://dx.doi.org/10.1007/s13146-011-0079-9

[27] Khodabakhshnezhad, A. and Arian, M. (2016) Salt Tectonics in the Southern Iran. International Journal of Geosciences, 7, 367-377. http://dx.doi.org/10.4236/ijg.2016.73029

[28] Arian, M. (2010) Tectonics and Sedimentation. Farazamin Press, Tehran, 307 p.

[29] Arian, M. and Maleki, Z. (2010) Principals of Experimental Tectonics. Asar Nafis Publication, Qum, 224 p.

[30] Pourkermani, M. and Arian, M. (1998) Tectonic Geomorphology of Salt Domes in West of Zanjan Province, Iran. Geographical Research, 47, 44-53. 
[31] Arian, M. and Feizi, F. (2010) The Significance of Faulting on the Surficial Spreading of Evaporitic Deposits in the Varamin-Semnan Area. Journal of Earth and Resources, 3, 1-20.

[32] Feizi, F., Arian, M. and Arian, A. (2015) Mud Diapirism on the Makran, Iran: Case Study on the Napag Mud Volcano. Open Journal of Geology, 5, 300-308. http://dx.doi.org/10.4236/ojg.2015.55027

[33] Arian, M. and Sistanipour, A. (2015) Mud Diapirism on the Gorgan, North Iran. Open Journal of Geology, 5, $442-450$. http://dx.doi.org/10.4236/ojg.2015.56041

[34] Arian, M. and Khodabakhshnezhad, A. (2015) Sedimentary Environments Can Be Changed by Geotechnology (Case Study: A Morphotectonic Idea for Design of Extensive Artificial Bay on the Iranian Plateau). International Journal of Geosciences, 6, 487-496. http://dx.doi.org/10.4236/ijg.2015.65039

[35] Arian, M. (2011) Middle East Tectonics. Asar Nafis Press, Qum, 236 p.

[36] Arian, M. (2010) Applied Seismotectonics. Farazamin Press, Tehran, 304 p.

[37] Arian, M. and Maleki, R. (2008) Neotectonics. Farazamin Research Center, Tehran, 150.

[38] Pourkermani, M. and Arian, M. (1998) Seismicity of Iran. Shahid Beheshti University Press, Tehran, 212.

[39] Pourkermani, M. and Arian, M. (1997) Seismotectonics. DezAb Consulting Engineers Company Press, Tehran, 270.

[40] Arian, M. and Aram, Z. (2014) Relative Tectonic Activity Classification in the Kermanshah Area, Western Iran. Solid Earth, 5, 1277-1291. http://dx.doi.org/10.5194/se-5-1277-2014

[41] Mashal, M., PourKermani, M., Charchi, A., Almasian, M. and Arian, M. (2013) Pattern of Structural Geology Underground in Eastern of North Dezfol Embayment. Advances in Environmental Biology, 7, 260-268.

[42] Pazhoohan, M., Arian, M., Ghorashi, M. and Khosrotehrani, K. (2014) A Study of Drainage Pattern Responses to Active Tectonics in Tadvan Region, SW Iran. Geodynamics, 1, 36-41.

[43] Rahimi, N. and Arian, M. (2014) Tectonic Geomorphology of Kangavar-Sosangerd Region, West Iran. Advances in Environmental Biology, 8, 119-124.

[44] Arian, M. and Hashemi, A. (2008) Seismotectonic Zoning in the Zagros. Journal of Sciences, 18, 63-76.

[45] Arian, M., Ahmadnia, A., Qorashi, M. and Pourkermani, M. (2002) Structural Analysis of Mengharak Transcurrent Fault System in Zagros, Iran. Special GEO 2002 Conference Issue Geoarabia, 7, 209-210.

[46] Arian, M., Qorashi, M., Pourkermani, M. and Ahmadnia, A. (2003) Fractal Analysis of Mengharak Transcurrent Fault System in Zagros, Iran. Proceedings of the 4th International Conference on Seismology and Earthquake Engineering, Tehran, 12-14 May 2003, 23.

[47] Baharvand, S., Pourkermani, M., Ajalloian, R., Arian, M. and Nouryazdan, A.R. (2010) Seymareh Landslide and Its Role in Environmental and Geomorphologic Changes of the Pole-Dokhtar Area. Journal of the Earth, 4, 13-24.

[48] Abdideh, M., Qorashi, M., Rangzan, K. and Arian, M. (2011) Assessment of Relative Active Tectonics Using Morphometric Analysis, Case Study of Dez River (Southwestern, Iran). Geosciences, 20, 33-46.

[49] Arian, M., Qorashi, M., Pourkermani, M. and Ahmadnia, A. (2006) The Structural Significance Kareh Bas Transcurrent Fault System in the Zagros Fold and Thrust Belt. Geosciences, 15, 126-133.

[50] Arian, M. and Noroozpour, H. (2015) Seismic Activity and Fractal Geometry of Kareh Bas Fault System in Zagros, South of Iran. Open Journal of Geology, 5, 291-299. http://dx.doi.org/10.4236/ojg.2015.55026

[51] Ehsani, J. and Arian, M. (2015) Quantitative Analysis of Relative Tectonic Activity in the Jarahi-Hendijan Basin Area, Zagros Iran. Geosciences Journal, 19, 751-765. http://dx.doi.org/10.1007/s12303-015-0016-3

[52] Omidali, M., Arian, M. and Sorbi, A. (2015) Neotectonics of Boroujerd Area, SW Iran by Index of Active Tectonics. Open Journal of Geology, 5, 309-324. http://dx.doi.org/10.4236/ojg.2015.55028

[53] Chegini, A., Sorbi, A. and Arian, M. (2015) Active Tectonics of Hamedan Area, SW Iran by Index of Active Tectonics. International Journal of Geology, 4, 108-118.

[54] Maleki, Z., Arian, M., Solgi, A. and Ganjavian, M.A. (2014) The Elements of Fold Style Analysis in the Khaftar Anticline, Zagros, Iran. Open Journal of Geology, 4, 79-92. http://dx.doi.org/10.4236/ojg.2014.43008

[55] Maleki, Z., Arian, M. and Solgi, A. (2014) Structural Style and Hydrocarbon Trap of Karbasi Anticline, in the Interior Fars Region, Zagros, Iran. Solid Earth Discussions, 6, 2143-2167. http://dx.doi.org/10.5194/sed-6-2143-2014

[56] Ehsani, J., Arian, M. and Ghorashi, M. (2015) Geomorphic Signatures of Active Tectonics in the Jarahi-Hendijan Drainage Basin in the South West Iran. Geosciences, 24, 211-218.

[57] Khodabakhshnezhad, A., Pourkermani, M., Arian, M., Matkan, A.A. and Charchi, A. (2015) Active Tectonics of Great Karounriver Basin. Geosciences, 24, 13-28.

[58] Maleki, Z., Arian, M., Solgi, A. and Ganjavian, M.A. (2015) Elements of Fold Style Analysis in the Karbasi Anticline, Interior Fars Region, Zagros. Geosciences, 24, 293-302. 
[59] Baratpour, F., Arian, M. and Solgi, A. (2015) Geometric Analysis of Tukak and Kamarun Anticlines on Izeh Zone, Zagros. Geosciences, 24, 191-200.

[60] Fard, N.G., Sorbi, A. and Arian, M. (2015) Active Tectonics of Kangavar Area, West Iran. Open Journal of Geology, 5, 422-441. http://dx.doi.org/10.4236/ojg.2015.56040

[61] Maleki, Z., Arian, M. and Solgi, A. (2015) Folding Pattern in the Fars Province, Zagros Folded Belt: Case Study on the Karbasi and Khaftar Anticlines, Interior Fars, Iran. Solid Earth Discussions, 7, 2347-2379. http://dx.doi.org/10.5194/sed-7-2347-2015

[62] Aram, Z. and Arian, M. (2016) Active Tectonics of the Gharasu River Basin in Zagros, Iran, Investigated by Calculation of Geomorphic Indices and Group Decision Using Analytic Hierarchy Process (AHP) Software. Episodes, 39, 3944. http://dx.doi.org/10.18814/epiiugs/2016/v39i1/89235

[63] Abdolizadeh, S., Maleki, Z. and Arian, M. (2016) Earthquake Hazard Zonation and Seismotectonics of the Bandar Abbas Area, Zagros, Iran. Open Journal of Geology, 6, 210-224. http://dx.doi.org/10.4236/ojg.2016.63019

[64] Hadizadeh, A., Arian, M. and Ganjouyan, M.A. (2011) Analysis Geometry Dashtak Detachment Zone in the Dashtak, Salamati and Sepidar Anticlines from Interior and Sub Coastal Fars Area. Journal of the Earth, 6, 33-44.

[65] Khodabakhshnezhad, A., Arian, M. and Pourkermani, M. (2008) The Elements of Fold Style Analysis in the Asmari Anticline (Zagros). Journal of Sciences, 18, 129-138.

[66] Khodabakhshnezhad, A., Arian, M. and Pourkermani, M. (2015) Folding Mechanism in the Asmari Anticline, Zagros, Iran. Open Journal of Geology, 5, 197-208. http://dx.doi.org/10.4236/ojg.2015.54018

[67] Arian, M., Pourkermani, M., Khodabakhshnezhad, A. and Noroozpour, H. (2011) Investigation of Oil Trap in the Asmari Anticline (Zagros, Iran). Indian Journal of Science and Technology, 4, 1696-1699.

[68] Alladin, Y., Talebian, M., Arian, M. and Ahmadi, M.M. (2015) Geotechnical Investigation and Seismic Zonation of Alluvial Deposits in Western Tehran. Geosciences, 24, 333-342.

[69] Taherkhani, B., Nazari, H., Pourkermani, M. and Arian, M. (2015) Geometry and Recent Kinematics of the North Qazvin Fault: Morphotectonic Approach. Geosciences, 24, 29-38.

[70] Manuchehri, H., Arian, M., Ghorashi, M., Solgi, M. and Sorbi, A. (2015) Geomorphic Signatures of Active Tectonics in the Chalus Drainage Basin in the Alborz, Iran. Geosciences, 24, 273-280.

[71] Noroozpour, H., Arian, M. and Sorbi, A. (2015) Fault Movement Potentials in the Tehran-Semnan Region (North Iran). Open Journal of Geology, 5, 281-290. http://dx.doi.org/10.4236/ojg.2015.55025

[72] Arian, M., Maleki, Z. and Noroozpour, H. (2011) Cenozoic Diastrophism and Deformational Events in the East Central Alborz. Journal of Basic and Applied Scientific Research, 1, 2394-2400.

[73] Feizi, F., Arian, A. and Rahmani, R. (2007) Seismotectonic Zoning in the Eastern Part of the Central Alborz. Journal of Sciences, 17, 151-164.

[74] Khavari, R., Arian, M. and Ghorashi, M. (2009) Neotectonics of the South Central Alborz Drainage Basin, in NW Tehran, N Iran. Journal of Applied Sciences, 9, 4115-4126. http://dx.doi.org/10.3923/jas.2009.4115.4126

[75] Arian, M. and Bagha, N. (2012) Active Tectonics of Tehran Area, Iran. Journal of Basic and Applied Scientific Research, 2, 3805-3819.

[76] Bagha, N., Arian, M., Ghorashi, M., Pourkermani, M., El Hamdouni, R. and Solgi, A. (2014) Evaluation of Relative Tectonic Activity in the Tehran Basin, Central Alborz, Northern Iran. Geomorphology, 213, 66-87. http://dx.doi.org/10.1016/j.geomorph.2013.12.041

[77] Arian, M. and Feizi, F. (2005) Application of Geomorphic Indices to the Assessment of Relative Tectonic Activity Levels in the Alborz-Central Iran Border Zone. Journal of Sciences, 15, 378-403.

[78] Arian, M., Bagha, N., Khavari, R. and Noroozpour, H. (2012) Seismic Sources and Neo-Tectonics of Tehran Area (North Iran). Indian Journal of Science and Technology, 5, 2379-2383.

[79] Moghimi, H., Arian, M. and Sorbi, A. (2015) Fault Movement Potential of Marzanabad Area, North Alborz, Iran. Open Journal of Geology, 5, 126-135. http://dx.doi.org/10.4236/ojg.2015.53012

[80] Arian, M. and Pourkermani, M. (2004) Tectonic Elements of South Flank in the East-Central Alborz Mountain. Journal of Sciences, Teacher Training University, 4, 359-368.

[81] Arian, M. and Qorashi, M. (2006) The Movement Potential Evaluation of the Major Quaternary Faults in Alborz-Central Iran Border Zone, from the East of Tehran to the East of Semnan. Journal of Geosciences, Geological Survey of Iran, 15, 184-188.

[82] Poroohan, N., Pourkermani, M. and Arian, M. (2013) An Assessment of Relationship in F-Parameter and Paleostress Fields in Heterogeneous Lithologies: Roudbar Area (Northwest of Iran). Australian Journal of Basic \& Applied Sciences, 7, 933-942. 
[83] Poroohan, N., Poukermani, M. and Arian, M. (2009) An Assessment on Correlations of Seismotectonic Parameters Preceding and Following Roudbar-Manjil Earthquake (Gilan, North of Iran). Australian Journal of Basic \& Applied Sciences, 3, 2643-2652.

[84] Farrokhnia, A.R., Pirasteh, S., Pourkermani, M. and Arian, M. (2011) Geo-Information Technology for Mass Wasting Hazard Zonation: Central-West Alborz-Iran. Disaster Advances, 4, 24-33.

[85] Khavari, R., Ghorashi, M. and Arian, M. (2009) Assessment of Relative Active Tectonics, South Central Alborz (North Iran). EGU General Assembly Conference Abstracts, 11, 1137.

[86] Sorbi, A., Arian, M. and Pourkermani, M. (2009) The Movement Potential Evaluation of the Major Quaternary Faults in Tehran Quadrangle. Journal of the Earth, 19, 176-182.

[87] Feizi, F. and Arian, M. (2006) The Classification of Thrust Fronts in the Alborz-Central Iran Border Zone from the East of Varamin to the East of Semnan. Journal of Sciences, 16, 75-87.

[88] Razaghian, G. and Arian, M. (2015) The Emergent Salt Diapirs in the East Zagros, Iran. Open Journal of Geology, 5, 718-726.

[89] Arian, M. and Pourkermani, M. (2004) Structural Significance of North Semnan and Attary Faults in Alborz-Central Iran Border Zone. Journal of Sciences, 14, 4551-4569.

[90] Arian, M. and Pourkermani, M. (2005) Cenozoic Diastrophism and Deformational Events in the Southern Flank of Central-East Alborz. Journal of Faculty Earth Sciences, 10, 43-51.

[91] Sadeghi, R., Saeedi, A., Arian, M., Ghorashi, M. and Solgi, A. (2015) Comparison of Strain Ellipsoid Shape in the South of Ardabil Range (NW), Based on the Results of the Magnetic Susceptibility Anisotropy and Paleostress Methods. Open Journal of Geology, 5, 611-622. http://dx.doi.org/10.4236/ojg.2015.59054

[92] Arian, M., Pourkermani, M., Qorashi, M. and Ghasemi, M.R. (2003) North Semnan Fault System and Its Role on Basin Division. Proceedings of the 8th Symposium of Geological Society of Iran, Shahrood, 4-6 September 2003, 11-17.

[93] Pourkermani, M. and Arian, M. (2001) Structural Geomorphology of Northeastern Kurdistan. Journal of Humanities, 7, 37-48.

[94] Mardani, Z., Ghorashi, M. and Arian, M. (2011) Geomorphic Signatures of Active Tectonics in the Talaghanrud, Shahrudand Sefidrud Drainage Basins in Central Alborz, N Iran. Geosciences, 20, 159-166.

[95] Sorbi, A., Arian, M. and Pourkermani, M. (2011) The Application of Geomorphic Indices to the Assessment of Relative Tectonic Activity Levels in Tehran Quadrangle. Journal of the Earth, 6, 1-9.

[96] Khavari, R., Ghorashi, M., Arian, M. and Khosrotehrani, K. (2010) Geomorphic Signatures of Active Tectonics in the Karaj Drainage Basin in South Central Alborz, N Iran. Geosciences, 19, 67-74.

[97] Mousavi, E.J. and Arian, M. (2015) Tectonic Geomorphology of Atrak River, NE Iran. Open Journal of Geology, 5, 106-114. http://dx.doi.org/10.4236/ojg.2015.53010

[98] Nouri, R., Jafari, M.R., Arian, M., Feizi, F. and Afzal, P. (2013) Correlation between Cu Mineralization and Major Faults Using Multifractal Modelling in the Tarom Area (NW Iran). Geologica Carpathica, 64, 409-416. http://dx.doi.org/10.2478/geoca-2013-0028

[99] Nouri, R., Jafari, M.R., Arian, M., Feizi, F. and Afzal, P. (2013) Prospection for Copper Mineralization with Contribution of Remote Sensing, Geochemical and Mineralographical Data in Abhar 1:100,000 Sheet, NW Iran. Archives of Mining Sciences, 58, 1071-1084. http://dx.doi.org/10.2478/amsc-2013-0074

[100] Nouri, R., Afzal, P., Arian, M., Jafari, M. and Feizi, F. (2013) Reconnaissance of Copper and Gold Mineralization Using Analytical Hierarchy Process in the Rudbar 1:100,000 Map Sheet, Northwest Iran. Journal of Mining and Metallurgy, 49, 9-19.

[101] Farrokhnia, A.R., Pirasteh, S., Pradhan, B., Pourkermani, M. and Arian, M. (2011) A Recent Scenario of Mass Wasting and Its Impact on the Transportation in Alborz Mountains, Iran Using Geo-Information Technology. Arabian Journal of Geosciences, 4, 1337-1349. http://dx.doi.org/10.1007/s12517-010-0238-7

[102] Arian, M. and Nouri, R. (2015) Lineament Tectonics and Mineralization in Tarom Area, North Iran. Open Journal of Geology, 5, 115-124. http://dx.doi.org/10.4236/ojg.2015.53011

[103] Feizi, F. and Arian, M. (2011) The Role of Structural Controllers in Geneses of Copper Deposits in 1:50000 Map of Saiin Qaleh. Journal of Sciences, 21, 1-10.

[104] Arian, M., Qorashi, M. and Ahmadnia, A. (2003) Analysis of Behbahan Shear Zone. Iranian Journal of Geology, 1, 14.

[105] Bahiraee, S., Arian, M., Qorashi, M. and Solgi, M. (2015) The Movement Potential Evaluation of the Mosha Fault (The West of Firoozkuh to the Shahrestanak). Geosciences, 24, 123-126.

[106] Bagha, N., Ghorashi, M., Arian, M., Pourkermani, M. and Solgi, A. (2015) Neotectonic Analysis of Mosha-North Te- 
hran Fault Zone, Based on Morphotectonic Features, Central Alborz, Northern Iran. Geosciences, 24, 41-52.

[107] Mosavi, E. and Arian, M. (2015) Neotectonics of Kashaf Rud River, NE Iran by Modified Index of Active Tectonics (MIAT). International Journal of Geosciences, 6, 776-794. http://dx.doi.org/10.4236/ijg.2015.67063

[108] Nouri, R. and Arian, M. (2015) Structural Control on the Distribution of Hydrothermal Alteration Zones and Mineralization in Dastjerdeh Area Based on Remote Sensing Data, NW Iran. Bulletin of the Georgian National Academy of Sciences, 9, 79-86.

[109] Khosroshahizadeh, S., Pourkermani, M., Almasiyan, M., Arian, M. and Khakzad, A. (2015) Evaluation of Structural Patterns and Related Alteration and Mineralization Zones by Using ASAR-ASTER Imagery in Siyahrood Area (East Azarbaijan—NW Iran). Open Journal of Geology, 5, 589-610. http://dx.doi.org/10.4236/ojg.2015.59053

[110] Sistanipour, A. and Arian, M. (2015) Geometric Analysis of Davaran Fault System, Central Iran. Open Journal of Geology, 5, 458-469. http://dx.doi.org/10.4236/ojg.2015.56043

[111] Nazemi, M., Ghorashi, M., Ghassemi, M.R. and Arian, M. (2015) Morphotectonics Features of Alluvial Fans Associated with Active Tectonics (Shotori Mountains, East of Tabas-Central Iran). Geosciences, 24, 91-100.

[112] Alizadeh, H. and Arian, M. (2015) Rule of Structural Factors in Formation of Porphyry Copper Deposits in South Western Part of Kerman Area, Iran. Open Journal of Geology, 5, 489-498. http://dx.doi.org/10.4236/ojg.2015.57045

[113] Mosavi, E.J. and Arian, M. (2015) Neotectonics of Tabas Area, Central Iran by Index of Active Tectonics (IAT). Open Journal of Geology, 5, 209-223. http://dx.doi.org/10.4236/ojg.2015.54019

[114] Daryani, N.J., Arian, M. and Omran, N.R. (2015) Tectonics and Mineralization of Copper in the Ardestan-Kahang Area, Central Iran by Remote Sensing. Open Journal of Geology, 5, 188-196. http://dx.doi.org/10.4236/ojg.2015.54017

[115] Arian, M. and Pourkermani, M. (2001) Rivers Morphology and Active Tectonic (Reviewing the Current Status of Ghezel Ozon River in the Province of Zanjan). Proceedings of the 5th Conference of Geological Society of Iran, Tehran, 28-30 August 2001, 556.

[116] Eshghi, Z., Arian, M. and Pourkermani, M. (2012) Structural Investigation on the Lak Mining Area (Bueen Zahra) Based on Remote Sensing, Used for Its Mineralization. Journal of the Earth, 6, 145-155.

[117] Arian, M., Toudeshki, V.H. and Noroozpour, H. (2011) Active Tectonics of Qezel Ozan River Basin, NW Iran. Journal of Applied Environmental and Biological Sciences, 1, 291-295.

[118] Alizadeh, H., Arian, M., Lotfi, M., Ghorashi, M. and Ghorbani, M. (2015) Determination of Porphyry Copper Deposit Locations Using Photo Lineament Factor in Northern Parts of the Dehaj-Sardoiyeh Belt. Geosciences, 24, $247-252$.

[119] Toudeshki, V.H., Pourkermani, M., Arian, M. and Khosrotehrani, K.H. (2011) Influence of Structures on the Ghezel Ozan River. Geosciences, 21, 55-60.

[120] Toudeshki, V.H. and Arian, M. (2011) Morphotectonic Analysis in the Ghezel Ozan River Basin, NW Iran. Journal of Geography and Geology, 3, 258-260. http://dx.doi.org/10.5539/jgg.v3n1p258

[121] Arian, M. (2015) Seismotectonic-Geologic Hazards Zoning of Iran. Earth Sciences Research Journal, 19, 7-13. http://dx.doi.org/10.15446/esrj.v19n1.40664

[122] Arian, M., Pourkermani, M., Sistanipour, A. and Noroozpour, H. (2011) Kinematic Significance of Fold- and FaultRelated Fracture Systems in the Rafsanjan’s Northeast Highlands (Central Iran). Journal of Basic and Applied Scientific Research, 1, 3398-3406.

[123] Arian, M., Pourkermani, M., Sistanipour, A. and Noroozpour, H. (2011) Seismicity and Fault Segmentation of BafqBaghin Fault System (Central Iran). Journal of Applied Environmental and Biological Sciences, 1, 382-396.

[124] Mosavi, E.J., Arian, M., Ghorashi, M. and Nazemi, M. (2012) Measurements of Geomorphic Indices in Tabas Area. Journal of the Earth, 7, 213-225.

[125] Arian, M. (2010) Earthquake-Fault Hazard Investigations in the Kerman Quadrangle. Journal of Sciences, 19, $176-182$.

[126] Arian, M. and Sorbi, A. (2011) Remote Sensing Investigation of the Faults and Lineaments in the Karaj-Qazvin Region. Journal of the Earth, 5, 21-34.

[127] Arian, M., Alizadeh, H. and Noroozpour, H. (2011) Satellite Geometry of Faults and Fractures and Its Relationship with Porphyry Deposits in Northern Parts of Dahaj-Sardoiyeh Belt, South of Iran. Indian Journal of Science and Technology, 4, 1303-1306. 


\section{Submit or recommend next manuscript to SCIRP and we will provide best service for you:}

Accepting pre-submission inquiries through Email, Facebook, LinkedIn, Twitter, etc.

A wide selection of journals (inclusive of 9 subjects, more than 200 journals)

Providing 24-hour high-quality service

User-friendly online submission system

Fair and swift peer-review system

Efficient typesetting and proofreading procedure

Display of the result of downloads and visits, as well as the number of cited articles

Maximum dissemination of your research work

Submit your manuscript at: http://papersubmission.scirp.org/ 